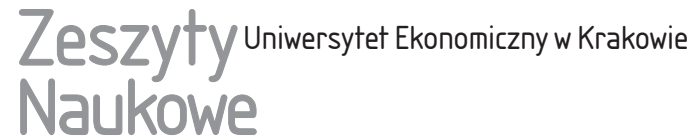

\section{Partial Effectiveness of Scientific Projects Financed through Public Funds*}

\begin{abstract}
One type of effectiveness is partial effectiveness determined while the project is on-going. It takes into account the progress of work being performed and the costs incurred. The article analyses and assesses the effectiveness of tools for monitoring the partial effectiveness of scientific projects. The specific goal is to determine the relationship between the current evaluation and partial effectiveness in relation to scientific projects.

Scientific projects financed within National Centre for Research and Development STRATEGMED programme is the subject of the analysis. An analysis of the funds disbursed to beneficiaries by NCRD has been performed with the use of the dynamic method (streaming), which consists in an analysing the cash flow between two subjects. The monographic method was used to analyse tools for monitoring partial effectiveness, enabling an examination of their features and components in detail.
\end{abstract}

Keywords: project, evaluation, effectiveness, beneficiary.

JEL Classification: O220, O320, O200.

Kamila Prucia, Cracow University of Economics, Doctoral Studies, Faculty of Finance and Law, Rakowicka 27,31-510 Kraków, e-mail: kamilaprucia@gmail.com

* This paper presents the results of a research project financed from Ministry of Science and Higher Education funds granted to the Faculty of Finance and Law at the Cracow University of Economics for research projects implemented by young scientists and doctoral research fellows. 


\section{Introduction}

The research done for this article was undertaken for two reasons. The first is that analysing the financing of science as a public task of a strategic nature for the state is important. The second is that there is a need to monitor and define ways of measuring and assessing the effectiveness of public funds intended for financing science. A difficulty in measuring the effectiveness of scientific projects is that this form of research is associated with uncertainty and risk. A significant part of research on effectiveness of the funding is carried out ex post. However, it should be considered whether the effectiveness of spending public funds should not be studied earlier - at the project implementation stage. In the last 20-30 years, there have been numerous changes in state management in the global environment. In terms of public expenditure as an instrument, how the economic and financial measures system is approached has changed. Science has developed significantly, as has practical experience "accountable management" in the public sector. It is a management model based on a measurement system which implies the need to implement the efficiency measurement function for the public sector (Lubińska 2007). The assessment of the effectiveness of public task implementation is systematised on two levels: macroeconomic and microeconomic. Public spending should be subject to modern procedures that result from the theory and practice of management, including (Owsiak 2004):

- budgeting by needs to plan expenses as needed,

- measuring the effects of public expenditure, i.e. measuring the achievements of units performing public tasks,

- taking into account achievements in the quality of public services during measurement,

- comprehensively evaluating budget programmes.

In recent decades, the most common method used to measure the effects and benefits of public expenditure has been the Data Envelopment Analysis, or DEA, whose progenitors referred to the productivity. The quotient of a single effect and a single expenditure was adopted as the measure of technical effectiveness (Owsiak 2015). J. Jakuszewicz (2015), examined how management instruments are shaped in the scientific research sector and how productivity of scientific units in Poland are measured in the context of parametric assessment of the Ministry of Science and Higher Education, using the DEA method. The research concludes that including a variable to characterise financial resources yields a more comprehensive explanation of the level of effects achieved. Financial expenditures on scientific activities determine the scientific effects achieved by researchers.

The general goal of the article is to analyse and assess the effectiveness of tools for monitoring the partial effectiveness of scientific projects. The specific goal is 
to determine the relationship between current evaluation and partial effectiveness in relation to scientific projects. The hypothesis is that on-going evaluation determines the partial effectiveness of a research project. For the needs of the study, selected evaluation tools used by the National Centre for Research and Development (NCRD) at the stage of carrying out a research project are anaysed.

\section{Using Public Funds to Finance Scientific Projects}

There are two forms of funding for science in the public sector - institutional funding and funding projects. The first consists in transferring grants to beneficiaries on the basis of performance indicators or based on negotiations, or direct selection of projects as well as programmes which are to be carried out. The second form, funding projects, consists in transferring grants of a limited size, budget and for a limited time to researchers or research teams, usually on the basis of project proposals describing anticipated research activity in terms of competition. In contrast to institutional funding, funding projects endow organisations with greater control. The current increase in financing projects at the cost of institutional financing is justified by the conviction that produces greater knowledge and better adjusts research to social and economic needs (Polityka naukowa... 2015).

The word "project" comes from the Latin word proiectus, "before an action". It is translated as the presentation of a description of a solution for a task to be performed in the future. According to the definition provided by the Project Management Institute, a project is temporary and its aim is to create a unique product (Stabryła 2006).

According to the definition of T. L. Young, a project is a specific set of operations designed to accomplish a singular goal, managed in an organised way. It has a defined beginning and end in time, for obtaining specific results which fulfill the needs of an organisation arising from its on-going business plans and its general concept of development (Drobniak 2005).

In a broad sense, a project is connected with a base solution (innovation), constituting a product characterised by an innovative form and construction, which will enable completion of an anticipated undertaking and the investment, operational and public task (Stabryła 2006). According to another definition, a project is a network of actions with precisely defined beginning and end in time (Spinner 1992).

A project should serve the purpose of e.g. (Pereginus 1990):

- providing essential infrastructure services and/or the further development of an institution, 
- increasing the value of goods by producing or processing them into a more valuable product,

- developing a nation's natural resources.

According to M. D. Rosenau, a project is characterised by four features which distinguish it from other anticipated and managed activities, including three-dimensionally defined objectives, uniqueness, use of resources and implementation within an organization. Three-dimensional objectives refer to the equivalent perception of a project's results, the time schedule and budget. A project's scope covers the anticipated and deliberate use of financial resources as well as those which are combined with human engagement. G. D. Oberlander defined a project as activity undertaken to achieve specific results by its beneficiary (Gorlewski 2015).

A scientific project as an undertaking being the subject of a grant agreement between executive agencies (National Centre for Research and Development, National Science Centre) and a beneficiary is a fundamental tool for financing science.

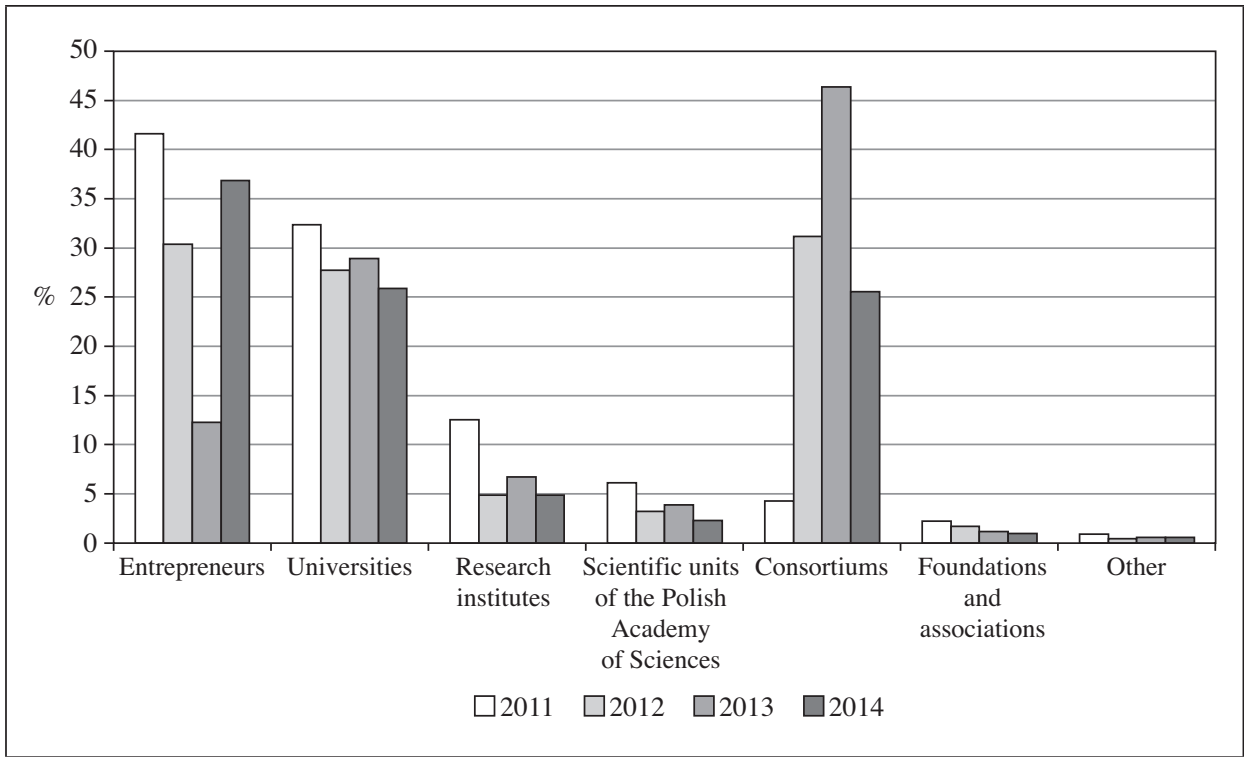

Fig. 1. Share of Scientific Projects Carried out by Individual Beneficiaries to the Total Number of Scientific Projects Implemented in the Period 2011-2014 (in \%)

Source: the author, on the basis of (NCBiR 2015, p. 71).

Figure 1 shows that in 2011 and 2014, entrepreneurs constituted the greatest group of beneficiaries of projects financed by the National Centre for Research and Development, while in 2012 and 2013 consortiums made up the largest group. 
The resources allotted for financing science as one of the categories of public tasks have been distinguished in the Budget Act in section 28 - Science. Figure 2 presents the amount of budget resources spent in section 730 in 2014 by task.

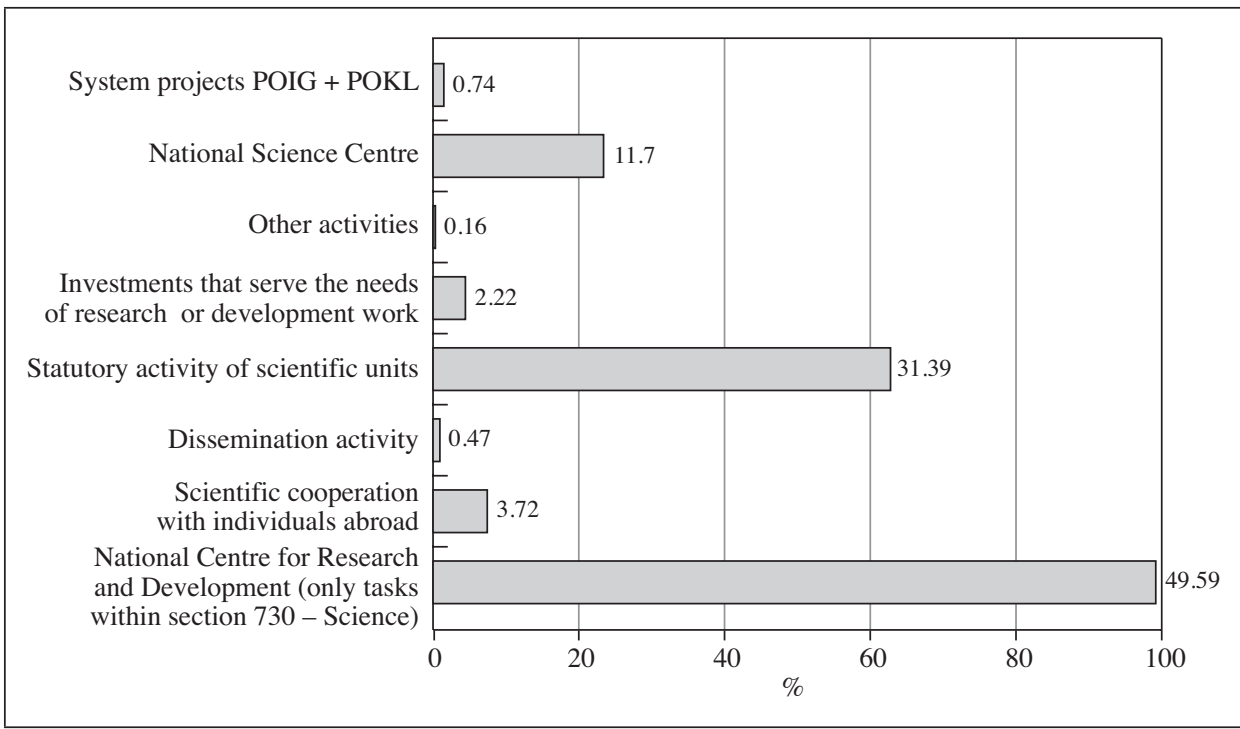

Fig. 2. Budget Expenses by Task in Section 730 - Science in 2014 (in \%)

Source: the author, on the basis of (NCBiR 2015, p. 18).

In 2014, expenses of the National Centre for Research and Development constituted the greatest group of budget expenses in section 730 - approximately $50 \% .32 \%$ of resources were spent for the statutory activity conducted by research units. The third largest category was the expenses of the National Science Centre.

\section{On-going Evaluation vs. Partial Effectiveness}

The source literature puts forward various approaches to interpreting the notion of effectiveness (Puczkowski 2014):

- an economic perspective - a relation between results and expenditures expressed through basic measures such as productivity, efficiency and profitability,

- a target perspective - evaluation of the degree to which the organisational objectives are attained, taking into account the economic perspective,

- a system perspective - evaluation of the use of organisational expenditures as well as the creation of specific relations with the environment, 
- a comprehensive perspective - an ability of the organisation to reach its operational objectives.

The term "effectiveness" has various meanings, so the scope of analyses on effectiveness must be defined in the subject literature. The ambiguity of the notion of effectiveness was stressed by citing a general inability to ascribe explicit empirical content, Z. Kowalski emphasised the ambiguity of the notion of effectiveness. The method of defining effectiveness is always dependent on the context of analysis or additional comment, the effectiveness of substitution, effectiveness of investment. A similar view is expressed in studies by other authors: E. Pasour claimed that the notion of effectiveness was always subjective and should be measured and defined in relation to the objective of the analysis (Szymańska 2010).

J. Zieleniewski, in a paper on the effectiveness of scientific research, emphasises that it may constitute a subject of an analysis in the scope of intended and on-going scientific activity: "Which we can have influence on as well as which is determined as an ex ante view" (Zieleniewski 1966). One may perceive every action as consisting of partial actions, in relation to which Zieleniewski distinguishes the following forms of effectiveness:

- general integral - integral due to costs and results,

- relative integral - partial due to results but integral due to costs,

- general partial - general due to results, partial due to costs,

- relative partial - partial due to both results and costs,

For the present analysis, relative partial effectiveness was used.

Evaluation means "assessing value". In the practice of Polish administration in the mid 1990s, evaluation meant simply "assessment". However, it is really only one component of assessment. As E. Stern points out, it is also the field of knowledge that combines applied science and the practice of public policy (Olejniczak 2008). In the practice of international organisations and public sector institutions, evaluation is defined through its practical objective - improving the quality of public interventions (Szymańska 2010, p. 20). For successful evaluation it is fundamental to determine the object and subject of evaluation precisely, logically and cohesively, and to ask the key questions to be answered as well as the criteria which will be used during the evaluation (PTE Evaluation Standards... 2017). A fundamental function of evaluation is correcting possible disturbances and problems which may appear in the course of carrying out tasks.

On-going evaluation is characterised by the following features (http://pte.org. pl/o-ewaluacji/, accessed: 21.08.2017):

- it is carried out in the middle of implementation of an intervention,

- the products and results reached at this stage of analysis are analysed,

- it conducts the first assessment of a project's and programme's quality upon completion, 
- it assesses the premises made at the programming stage (objectives, rates),

- it evaluates the context of a project's implementation,

- it may contribute to some modifications being made in the implementation of interventions and the updating the assumptions adopted.

These features show that there is a relationship between the on-going evaluation and assessment of a project's partial effectiveness. Performance of the on-going evaluation provides information on the output indicators.

\section{Tools Used by the National Centre for Research and Development in Monitoring Partial Effectiveness}

\subsection{General Remarks}

The National Centre for Research and Development conducts scientific research serving practical implementations. This field has been divided into six subfields (Table 1). To analyse on-going evaluation, the STRATEGMED programme was chosen. It is classified under the first area introduced in Table 1 - financing applied research. The main objective of the STRATEGMED programme is to eliminate diseases of affluence and regenerative medicine on the basis of scientific research and developmental works carried out in four fields: cardiology and heart surgery, oncology, neurology and the senses, and regenerative medicine (http://www.ncbr. gov.pl/programy-strategiczne/profilaktyka-i-leczenie-chorob-cywilizacyjnych--strategmed/, accessed: 24.08.2017).

Table 1. Financing Actions Taken in Scientific Research with Practical Use in 2015

\begin{tabular}{|l|c|c|}
\hline \multicolumn{1}{|c|}{ Subfield } & $\begin{array}{c}\text { 2015 Scheme } \\
\text { (Thousands } \\
\text { of PLN) }\end{array}$ & $\begin{array}{c}\text { Performance } \\
\text { in 2015 } \\
\text { (Thousands } \\
\text { of PLN) }\end{array}$ \\
\hline Financing applied research & 663,181 & 660,904 \\
\hline $\begin{array}{l}\text { Financing R+D research and commercialisation } \\
\text { of the results in subjects which can be applied in practice }\end{array}$ & $1,632,619$ & $1,178,358$ \\
\hline $\begin{array}{l}\text { Developing R+D staff competences and increasing } \\
\text { awareness of the role science plays in economic development }\end{array}$ & 26,948 & 24,139 \\
\hline R+D support in national defence & 348,737 & 346,953 \\
\hline $\begin{array}{l}\text { Financing the "Improvement of the working and safety } \\
\text { conditions" multiannual programme - Stage 3 }\end{array}$ & 10,500 & 10,500 \\
\hline Support for common infrastructure of research units & $1,850,252$ & $1,748,471$ \\
\hline
\end{tabular}

Source: the author, on the basis of (NCBiR 2016, p. 102-126). 


\subsection{Partial Effectiveness in Relation to the NCRD Programmes}

Cohesion and effectiveness are the most important criteria in evaluating the NCRD programmes. The first criterion - an internal examination - evaluates the programme for its transparency, clarity of concept and functionality of the solutions proposed. The external evaluation of the premises where the programme is conducted in relation to objectives of national scientific policy and innovative policy is determined in the National Research porgramme, among others. The second criterion - effectiveness - concerns the possibility of reaching the programme's objectives, assessing its qualifications and a proposed rating system (http://archiwum.opolskie.pl/docs/9._prof._kurzydlowski_x_n.pdf, accessed: 24.08.2017).

Within the first subfield defined in the field of scientific research serving for practical use - financing applied research - NCRD described the main objective as an increase of intensity of the research used for the purposes of the economic sector. The main rate of the first action has also been defined as the number of enterprises carrying out projects in the scope of applied research in cooperation with research units. The anticipated value of the rate at the end of 2015 was 380 , while the actual performance came out at 502. This higher performance came thanks to two factors: redeployments in the timetable for the implementation of the project and a higher number of enterprises participating in new projects than had been expected according to assessments.

Financing applied research was accomplished in 2015 through (NCBiR 2016, p. 102-106):

- preparation of contest documentation,

- announcing a competition,

- call for applications,

- evaluation and selection of applications to be covered with financing,

- concluding agreements with development contractors,

- supervision of the execution and financing of projects,

- settlement of projects,

- ex ante, on-going, mid-term, ex post.

14,272 thousands of PLN was spent in 2015 within the resources allotted to service, supervision, dissemination of information on competitions and the popularisation of the effects of the measures taken within applied research as well as evaluation (NCBiR 2016, p. 102-106).

\subsection{Partial Effectiveness in Relation to Beneficiaries of Resources}

A fundamental project document that includes obligatory guidelines for on-going evaluation is the financing agreement between beneficiaries of 
resources and the National Centre for Research and Development. It states that, to evaluate the project while it is being implemented, the beneficiary is obliged to cooperate with the Centre or an entity authorised by the Centre as well as to provide information concerning the project involved, particularly to submit information about the economic effects and other benefits incurred as a result of its implementation (http://www.ncbr.gov.pl/gfx/ncbir/userfiles/_public/programy_ strategiczne/strategmed/ii_konkurs/wzor_umowy_strategmed_iikonkurs.pdf, accessed: 23.08.2017).

Within the project implementation period, the contractor is obliged to submit to annual reports to NCRD, whose assessment is to determine whether (http:// www.ncbr.gov.pl/gfx/ncbir/userfiles/_public/programy_strategiczne/strategmed/ ii_konkurs/wzor_umowy_strategmed_iikonkurs.pdf, accessed: 23.08.2017):

1) implementation of the project is in line with the agreement,

2) continuing the project will achieve the intended objectives.

In the event basic, industrial research or development works results indicate lack of possibilities for reaching project objectives, the contractor is obliged to immediately inform NCRD if the project objectives cannot be achieved, and then to apply to cease the project (http://www.ncbr.gov.pl/gfx/ncbir/userfiles/_public/ programy_strategiczne/strategmed/ii_konkurs/wzor_umowy_strategmed_ iikonkurs.pdf, accessed: 23.08.2017).

Table 2. Selected Product Rates within the STRATEGMED Programme in 2015

\begin{tabular}{|l|c|c|c|}
\hline \multicolumn{1}{|c|}{ Rates } & $\begin{array}{c}\text { Target } \\
\text { Value }\end{array}$ & $\begin{array}{c}\text { The Value } \\
\text { Planned } \\
\text { in 2015 }\end{array}$ & $\begin{array}{c}\text { The Value } \\
\text { Reached } \\
\text { in 2015 }\end{array}$ \\
\hline $\begin{array}{l}\text { Number of publications on R+D works of programmes } \\
\text { whose authors are members of research teams } \\
\text { in periodicals included in the Science Citation Index }\end{array}$ & 200 & 15 & 6 \\
\hline $\begin{array}{l}\text { Number of new research teams formed to implement } \\
\text { projects within the programme }\end{array}$ & 40 & 9 & 56 \\
\hline Number of patent applications in PCT and EPO mode & 50 & 1 & 3 \\
\hline
\end{tabular}

Source: the author, developed on the basis of (NCBiR 2016, p. 102-106).

Table 2 presents demonstration product rates reported at the stage of implementation of the project in the annual report by beneficiary. Where there are deviations from the planned value, it is necessary to explain their causes.

The scientific project is implemented according to a schedule and activity-based budget - every research task has a budget and scope of work to perform. In partial settlement reports (annual), the beneficiary of a scientific project is obliged to indicate the level of work performance based on rates which are defined 
at the planning stage in the application for a grant. The mechanism for evaluating an on-going project in material and cost scope allows for an analysis of the partial effectiveness of a scientific project.

\section{Conclusion}

The National Centre for Research and Development performs on-going evaluation at two levels. One directly concerns the beneficiaries in the scope of assessment of advancement of works as well as incurred costs. The other holistically assesses the effectiveness of all programmes implemented by the National Centre for Research and Development. At both levels, the Centre adopts indicators which are usually determined in periodic reports.

Effectiveness is one of the criteria of evaluation. In this aspect, effectiveness focuses on an analysis of the relationship between expenditures, costs, resources (human, financial, administrative) and the effects achieved. The on-going evaluation of a project enables the analysis of partial effectiveness. STRATEGMED, an NCRD programme, has clearly defined output indicators, and indicates the planned annual and target value.

With regard to the assessment of the effectiveness of partial effectiveness monitoring tools, it should be stated that the National Centre for Research and Development obliges beneficiaries of scientific projects to submit annual reports on project implementation. However, these reports should not only fulfill a reporting function but also a control function. The information contained in the annual report should be the starting point for further analyis in two main areas: compliance of project implementation with the financial agreement, and adequacy of the level of funds spent in relation to the level of the output indicators.

On-going evaluation makes it possible to assess the risk of a project moving away from its conceptual design. Therefore, monitoring the partial effectiveness of a scientific project protects against the risk of losing financing due to lack of implementation in operational objectives.

\section{Bibliography}

Drobniak A. (2005), Ocena projektów publicznych [Evaluation of public projects], Akademia Ekonomiczna w Katowicach, Katowice.

Gorlewski B. (2015), Project Effectiveness Evaluation, Szkoła Główna Handlowa w Warszawie, Warszawa.

Jakuszewicz J. (2015), Analysis and Assessment of the Productivity of Scientific Units, doctoral dissertation, Politechnika Poznańska, Poznań. 
Lubińska T. (2007), Budżet zadaniowy w Polsce. Reorientacja z wydatkowania na zarzadzanie pieniędzmi publicznymi [Task budget in Poland. Reorientation of spending for managing public money], Difin, Warszawa.

NCBiR (2015), Sprawozdanie z działalności NCBiR za rok 2014 [Report on the activities of NCRD for 2014], Warszawa.

NCBiR (2016), Sprawozdanie z działalności NCBiR za rok 2015 [Report on the activities of NCRD for 2015], Warszawa.

Olejniczak K. (2008), Teoria i praktyka ewaluacji interwencji publicznych [The theory and practice of evaluating public interventions], Wydawnictwa Akademickie i Profesjonalne, Warszawa.

Owsiak S. (2004), O nowatorskie podejście do sektora publicznego [For an innovative approach to the public sector] (in:) Nauki finansowe wobec współczesnych problemów gospodarki polskiej [Financial sciences in the face of contemporary problems of the Polish economy], t. 1, Finanse publiczne [Public finances], Akademia Ekonomiczna w Krakowie, Kraków.

Owsiak S. (2015), Finanse [Finance], PWN, Warszawa.

Perspectives on Project Management (1990), R. N. G. Burbridge (ed.), Peregrinus, London.

Polityka naukowa - słownik encyklopedyczny [Scientific policy - encyclopedic dictionary] (2015), MNiSW, Departament Innowacji i Rozwoju, http://www.nauka.gov.pl/g2/ oryginal/2015_02/75745082fb8845f570c6c60d435a5259.pdf (accessed: 23.03.2017).

PTE Evaluation Standards (2017), http://pte.org.pl/standardy-ewaluacji-pte/ (accessed: 21.08.2017).

Puczkowski B. (2014), Efektywność zarządzania środkami publicznymi [Effective public fund management], UMW, Olsztyn.

Spinner M. P. (1992), Elements of Project Management, Prentice Hall, Englewood Cliffs.

Stabryła A. (2006), Zarzadzanie projektami ekonomicznymi i organizacyjnymi [Managing economic and organisational projects], PWN, Warszawa.

Szymańska E. (2010), Efektywność przedsiębiorstw - definiowanie i pomiar [Enterprise effectiveness - defining and measurement], http://www.wne.sggw.pl/czasopisma/pdf/ RNR_2010_T97_z2_s152.pdf (accessed: 1.04.2017).

Zieleniewski J. (1966), Efektywność badań naukowych [Effective scientific research], PWN, Warszawa.

\section{Efektywność cząstkowa projektów naukowych finansowanych ze środków publicznych}

(Streszczenie)

Jednym z rodzajów efektywności jest efektywność cząstkowa określana na etapie realizacji przedsięwzięcia z uwzględnieniem zaawansowania wykonania prac oraz poniesionych kosztów. Celem artykułu jest analiza oraz ocena skuteczności narzędzi monitorowania efektywności cząstkowej projektów naukowych, a w szczególności określenie zależności między ewaluacją bieżącą a efektywnością cząstkową w odniesieniu do projektów naukowych. Przedmiotem analizy są projekty naukowe finansowane w ramach programu Narodowego Centrum Badań i Rozwoju (NCBiR) - STRATEGMED. Analiza wydatkowania 
środków przekazanych beneficjentom przez NCBiR została dokonana z zastosowaniem metody dynamicznej (strumieniowej), której istotą jest analiza przepływu środków pieniężnych między dwoma podmiotami. Metoda monograficzna posłużyła do analizy narzędzi monitorowania efektywności cząstkowej, umożliwiając szczegółowe zbadanie ich cech i elementów.

Słowa kluczowe: projekt, ewaluacja, efektywność, beneficjent. 